\title{
Instruments for analysing urban conflicts in the Global South: The case of urban transformation processes in Dakar
}

\author{
Eva Álvarez de Andrés ${ }^{a, *}$, José Miguel Fernández Güell ${ }^{\text {b }}$, Harry Smith c \\ a Grado en Fundamentos de la Arquitectura, Universidad Rey Juan Carlos, Camino del Molino, 28943, Fuenlabrada, Madrid, Spain \\ ${ }^{\mathrm{b}}$ Escuela Técnica Superior de Arquitectura de la Universidad Politécnica de Madrid, Avenida de Juan de Herrera, 4, 28040, Madrid, Spain \\ ' School of Energy, Geoscience, Infrastructure and Society (EGIS), Heriot-Watt University, Riccarton, Edinburgh, EH14 4AS, Scotland, UK
}

\section{A R T I C L E I N F O}

\section{Article history:}

Received 18 December 2014

Received in revised form 24 April 2015

Accepted 21 May 2015

Available online $\mathrm{xxx}$

\section{Keywords:}

Urban governance

Conflicts of interests

Citizen mobilization

Dakar

Global South

\begin{abstract}
A B S T R A C T
Physical and social transformation processes that take place in urban contexts with strong spatial growth and hardly any economic development frequently have significant adverse impacts for the affected people, which tend to be made invisible. This paper presents an analytical framework to explore different ways to approach urban transformation processes (supply side), their impacts on the set of needs of the community (demand side) and their consequences on the urban environment as a whole (context). The proposed method has been used to assess three actions related to the physical and social transformation of the largest self-made settlement in the city of Dakar, Senegal, during the 2005-2012 period. Research findings show how exogenous interests are privileged over the common good when the affected citizens are not effectively involved in decision-making processes.
\end{abstract}

(c) 2015 Elsevier Ltd. All rights reserved.

\section{Introduction}

In an urban context with spatial growth and scant economic development, slum upgrading in self-made settlements becomes a key management issue in many countries of the South (Jenkins, Abiko, Frediani, \& Moraes, 2010). Nevertheless, several authors (Burgess, Carmona, \& Kolstee, 1997; Davis, 2006; Frediani, 2007; Payne, 2002; Payne, Durand-Lasserve, \& Rakodi, 2009) have noted that this type of programme, though justified for improving physical aspects of the self-made settlements, can have very negative impacts for the settlers themselves as well as for the urban environment as a whole. In fact, these programmes frequently entail the eviction of residents and tend to aggravate social segregation and inequities. In the case of Dakar city (Senegal), estimations indicate that slum upgrading programmes have evicted nearly 70\% of original residents (Durand Lasserve \& Ndiaye, 2008). As recognised by a World Bank report (World Bank, 2001), these upgrading processes generally imply "involuntary relocation" and frequently end up in loss of economic activities and destruction of mutual-support social networks among residents. Moreover, these

\footnotetext{
* Corresponding author.

E-mail addresses: eva.alvarez@urjc.es (E. Álvarez de Andrés), josemiguel. fernandez@upm.es (J.M. Fernández Güell), H.C.Smith@hw.ac.uk (H. Smith).
}

negative impacts tend to be made invisible (Shiva, 2005) either because of lack of interest in assessing the programmes' outcomes (Jenkins et al., 2010) or because the programmes are assessed by their own promoters and not by their recipients (Álvarez, 2013).

On the other hand, since the 1990s it has been widely accepted that self-made settlements are not the problem, but the solution found by people to satisfy their housing needs (Bredenoord \& van Lindert, 2010; Burgess, 1992; Burgess et al., 1997; Gaye, 1992; Jenkins, Smith, \& Wang, 2007; Moser, 1998; Purcell, 2002; Tunas \& Peresthu, 2010). Slum residents are not passive agents; on the contrary, they put a lot of effort into building their houses and neighbourhoods (Fall, 2007; Gaye, 1992; Landman and Napier, 2010; Mitlin, 2008; Neuwirt, 2011). Nevertheless, it is still a significant challenge to get governments and funding agencies to recognize them as active agents of change and, therefore, support their efforts (Satterthwaite, 2008).

For this reason, it is critical that policies, programmes and actions oriented to urban transformation contribute decisively to satisfy the needs of the affected people and to improve the urban environment as a whole. That is why a growing number of scholars (Fernández-Güell, 2006; Marais \& Ntema, 2013; Peris, AcebilloBaqué, \& Calabuig, 2011; Scott, Cotton, \& Sohail Khan, 2013; Taleai, Sliuzas, \& Flacke, 2014) have argued the need to take into consideration the complexity of these processes. The 
heterogeneous nature and intricate relationships of the functional elements and the stakeholders involved in urban processes add difficulty to the analysis. In order to fully understand the spatial and social transformation processes in large urban areas, it is necessary to analyze at least three elements: the multidimensional needs of residents (Max-Neef, Elizalde, \& Hopenhayn, 2010); the process dynamics generated by stakeholders (Escobar, 2005; Frediani, 2007); and the societal, economic, physical and political context in which the transformation takes place.

Other authors (Post \& Mwangi, 2009; Ridge \& Wright, 2008) emphasize that these analyses should be carried out in real contexts, generally characterized by unequal power relations (Chang, 2008), in which the interests of minority groups tend to prevail over the needs of the overall community (Harvey, 2012; Jenkins et al., 2007). Lastly, the importance of incorporating the experience and knowledge of those affected by the transformation processes should be stressed (Frediani, 2007; Maf-Neef et al., 2010; Wresinnski, 1980).

This paper presents a method to analyze spatial and social transformation processes based on two key components. Firstly, a so-called "functional system", based on a systemic approach (Kauffman, 1995; Von Bertalanffy, 1968; Waldrop, 1992), is used to analyze the complexities of the case studies. Secondly, the process of gathering information has been carried out following a bottomup approach so as to incorporate on an equal basis the opinions of stakeholders and affected people. This method has been used to assess three recent transformation cases (2005-2012) undertaken in the suburbs of Dakar and promoted by different agents: National Government (case 1), development agencies (case 2) and common citizens (case 3 ). The three initiatives took place in Pikine Irregular South (PIS), a settlement traditionally ignored by public institutions and characterized by high levels of social exclusion, poverty, and physical deterioration (see Fig. 1).

The proposed method has contributed to make visible the impacts generated by diverse initiatives on the needs of the resident population and on the urban environment. In addition, the research has shown the unbalanced relations between stakeholders and how the interests of promoters and managers of public policies prevail over the community's general interest.

This study makes three major contributions. Firstly, the analytical method demonstrates its validity to analyze complex social-spatial transformation processes. Secondly, case studies show that in order to improve citizens' living conditions, actions for transforming self-made settlements must pursue the satisfaction of residents needs in an integrated way (Max-Neef et al., 2010), must avoid the prevalence of external interests (Jenkins et al., 2007; Michelutti \& Smith 2014), and must involve residents in the decision-making process (Escobar 2005; Frediani, 2007). Lastly, the study presents a detailed analysis of the spatial and social transformation process that is taking place in the Dakar region.

The paper is structured in six parts. After the introduction, the method used in the research is explained, including the analytical framework which was applied in the research as a basis for understanding the case studies. Part 3 presents the context in which the case studies have evolved. Part 4 and 5 present research findings from initiatives promoted by the public authorities (cases 1 \& 2 ) and the citizens (case 3). Part 6 reflects the tentative conclusions that can be withdrawn from the findings.

\section{Method, case studies selection and data collection}

\subsection{Analytical framework}

This research aims to assess the extent to which actors whose role is in great part justified, at least in theory, on the basis of working towards the improvement in people's living conditions (national and local governments, 'aid' agencies), really respond to this objective in their real practices in transforming the territory. In addition, the research aims to assess the consequences of their actions on the residents and the urban context.

To fulfil this purpose, a so-called "functional system", based on complexity and systems theory (Kauffman, 1995; Von Bertalanffy, 1968; Waldrop, 1992), has been designed to conceptualize and expose the complex relationships among demand, supply, and

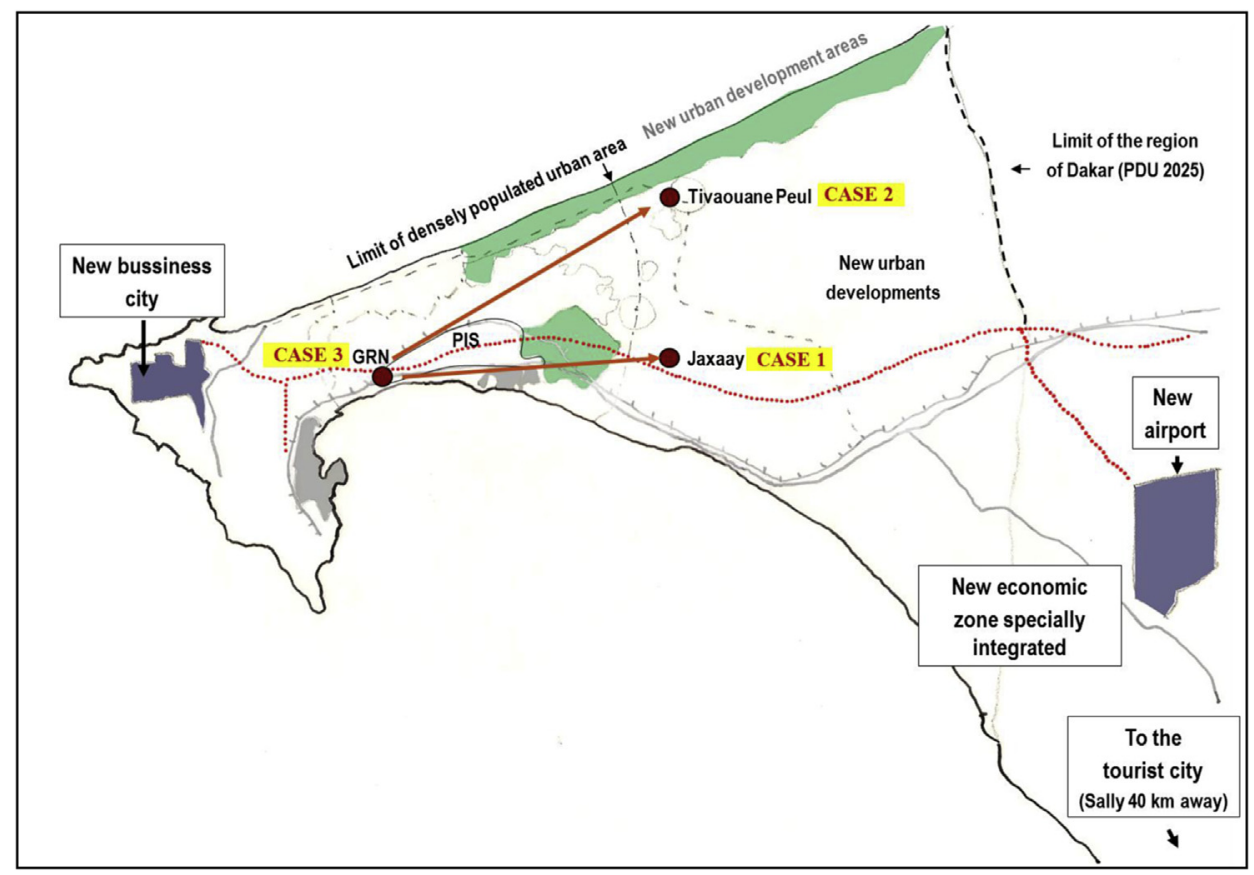

Fig. 1. Location of PIS and case studies in Dakar region.

Source: Authors, based on information from (République du Sénégal, 2006). 
context (see Fig. 2).

The concept of demand refers to the requirement, by residents, to satisfy a set of needs - social, economic, physical and political. The concept of supply is meant hereby as a series of operational processes and agents which try, at least according to their stated aims, to provide satisfaction to people's needs. The concept of context is understood as a series of economic, spatial, societal and political factors that shape and affect the operation of an urban area.

Meeting people's needs is at the centre of the functional system, as is shown in Fig. 2. Our starting point is that the legitimate ultimate aim of most actions which transform the territory (in terms of human impact) is the improvement of residents' living conditions. Even in cases of operations to transform the territory where there are other interests, which are often 'hidden', the explicit public justification given for them is precisely the improvement of citizens' living conditions in general, and of those directly affected in particular, as the case studies presented in this paper show.

The analytical framework was designed taking this 'rhetorical' positioning as a starting point, which does not mean that we ignore the interests that motivate those promoting and managing processes of transformation of the territory to act. The intention in applying the functional system as an analytical tool is precisely to contribute to showing the gap between the rhetoric that is used to justify the implementation of such processes and their real consequences on both meeting demand and shaping the supply and context overall. Applying the functional system as a tool to analyze real cases of territorial transformation can help to make visible the 'hidden' interests of the various actors.

In order to understand the characteristics of a particular functional system as defined above (see Fig. 2), its components can be explored by addressing the following questions:

- How has demand been defined and recognised?

- How has supply been geared towards satisfying the demand, and how has this supply been structured and organized?

- To what extent has the implementation of the initiative contributed to improving (or not) the context (e.g. in terms of economic self-sufficiency, environmental sustainability, social equity and institutional legitimacy - Álvarez, 2013; Belil, Borja, \& Corti, 2012; Fernández-Güell, 2006)?

In summary, this is a heuristic instrument used to understand the reality.

\subsection{Premises of the research}

The research was based on the following pre-established premises:

- In order to explore real cases, it uses a case study approach (Anderson, 1983; Gersick, 1988; Harris \& Sutton, 1986; Kidder, 1982; Pinfleld, 1986).

- The researcher is not a neutral agent (Jenkins et al., 2007; Myrdal, 1972), and we acknowledge our positioning in favour of processes that empower people to meet their needs, which entails questioning relations of power, whilst at the same time ensuring that this does not detract from a rigorous application of social science methods (Álvarez, 2013).

- Data collection in this kind of research needs to be structured from bottom up, with the aim of giving voice to the widest possible range of actors, particularly those who tend to be rendered 'invisible' (Freire, 1970; Maf-Neef et al., 2010; Wresinski, 1980).

\subsection{Data collection and analysis}

Data collection and analysis comprised four stages: immersion (description); systematic data collection (classification); data processing (making connections); and drawing conclusions (producing an account) (Frediani, 2007).

With regard to the immersion (description) stage, the research reported on in this paper was supported from its inception by All Together for Dignity (ATD) Fourth World, which has over 25 years of experience in supporting the most vulnerable households in the settlement that this paper focuses on. This support was invaluable in enabling the researchers to access the views of those affected by the processes of peri-urban transformation in Dakar that were explored in the research. In 2008 the research was made part of a wider action-research process that was initiated to develop a closer link between ATD and the university that the lead investigator was based at. This university has contributed to actions supported by ATD (case study 3 below) by collecting data, developing plans and helping local leaders and ATD present their initiatives and outcomes to local and national authorities. This link was made possible through the continuous presence on site, since 2008, of final year students and researchers. ATD's direct involvement in the research reported on in this paper took place through introducing the researchers to the neighbourhoods so as to enable the organisation of focus groups, providing feedback on the design of the research, and sharing their analysis of the findings (i.e. they contributed to achieving a degree of co-production of the research).

Systematic data collection (classification) took place between 2009 and 2012. Documents and grey literature on the case studies

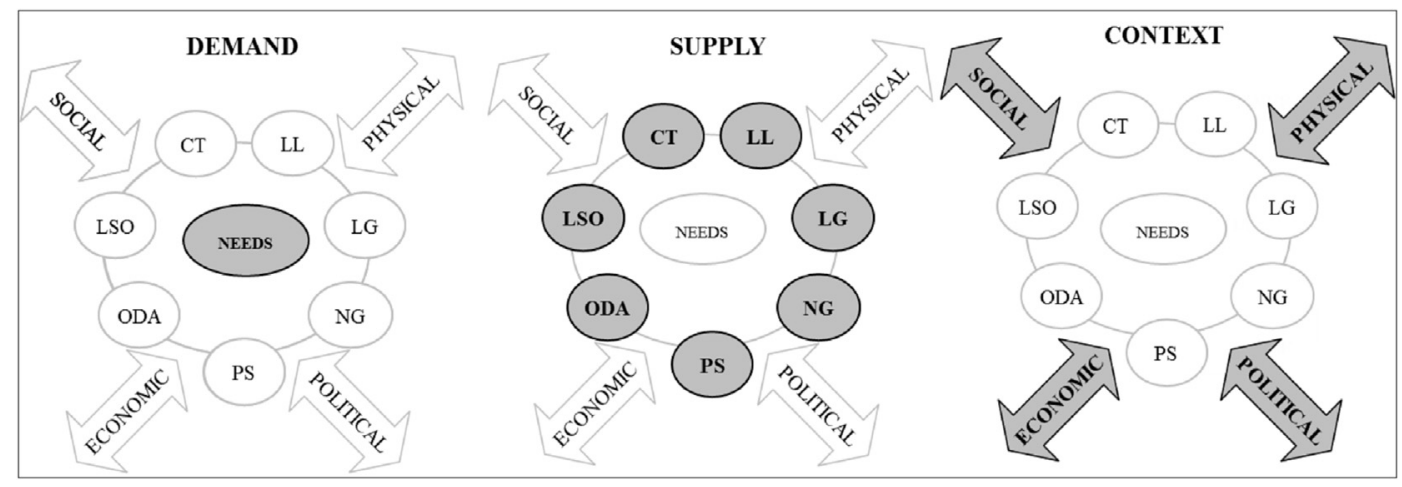

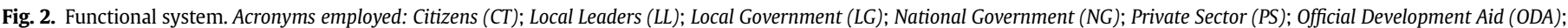
Local Support Organizations (LSO).

Source: Authors. 
were collected, and twelve focus groups (4 per case study) were held with citizens who were affected by the case study initiatives, with the objective of defining and analysing the range of needs, as well as the way in which these were met, or not, by the various actors in each of the case studies. Assessment of needs was based on the theory of human needs developed by the Escuela de Desarrollo a Escala Humana (EDEH - School of Development at the Human Scale - see Max-Neef et al., 2010), which argues that human needs are few, finite and universal, and that what changes in space and time are not those needs, but the way in which they are met. Group participants were segmented by sex, age and vulnerability risk in four groups: adult men, adult women, youth and socially excluded population. In addition, fifty-six semi-structured interviews were held with stakeholders to contrast with focus group contributions. Stakeholders belonged to development agencies, National Government, municipalities, NGOs and local leaders. Altogether, 196 persons participated in the research project.

Data processing (making connections) and drawing of conclusions (producing an account) took place from 2012 to 2014. Finally, in June 2014 the research findings were disseminated in Dakar, through video presentations in the settlements affected by the case study initiatives, as well as at the newly established "Ministère de la reestructuration et de l'amenagemet des zones d'inondaction" (MRAZI), the latter being attended by participants in the research involved in all three case studies: national and local authorities, NGOs, ATD members and people affected by the initiatives. Over 150 people took part in the local dissemination events.

\subsection{Case studies selection}

The explanatory power of the tool was tested with three cases that reflect the spatial and social transformation of peri-urban Dakar. These cases were selected in order to be comparable, as they share the same demand and context, but at the same time they differ in the relationship patterns among stakeholders. In other words, the selected cases show different ways of implementing policies and actions, while they purport to satisfy similar demands (at least in their rhetoric) and operate within the same context.

As is detailed in the following section, the three selected case studies affected residents in peri-urban Dakar, and more specifically Pikine Irregular South. In all the selected cases, the stated justification for the initiative was the improvement of living conditions of Dakar citizens in general, and of those directly affected in particular. In case study 1 , for example, it was stated that the plan had emerged with the intention of responding to the problem of flooding at a national level, establishing the objective of "allowing each family affected by flooding to access decent housing, based on their means and needs" (ENDA, 2008:82). In case 2, it was stated that the action would contribute to generate new jobs, achieve territorial equilibrium and improve urban mobility (République du Sénégal-APIX, 2007); in addition, following World Bank stated policies, those affected were to see their living conditions improved or at least maintained, as is detailed further in the following section (World Bank, 2001). However, once both initiatives had been implemented, according to experts the works had not succeeded in fighting floods (case 1) or generating employment and improving territorial equilibrium (case 2). Moreover, those affected by both these cases maintained that they had been impoverished and their social networks weakened or dispersed. In addition to their stated aims to meet demand, both cases were selected because their analysis allowed an exploration of how public authorities operate in practice in transforming peri-urban Dakar. Case 1 provides an illustration of the national government's modus operandi, while case 2 exemplifies the practices of international actors such as the
World Bank or firms based in the Global North.

Case study 3 shows the reaction of a community affected by the previous two cases ( 1 and 2 ). Given the absence of an effective response from the authorities to this community's needs, it decided to self-organize and act using its own resources (such as time, voluntary work, etc.). This case was selected to illustrate how residents can act in a bottom-up approach.

The next section presents the context for, and further detail on, each of the three case studies. This is followed by the findings from the case studies, which are grouped to present findings from cases promoted by public authorities on the one hand (case studies 1 and 2) and a bottom-up initiativeon the other (case 3).

\section{Case studies context}

In this section a brief historical and contextual description is given of the study area so as to provide a better understanding of the urban transformation processes.

\subsection{The origins of pikine}

Pikine was founded in the seventies as a provisional camp to accommodate displaced people from the centre of Dakar by an urban renovation programme (Vernière, 1977; Salem, 1998; DorierApprill, 2000). Despite being located far away from the center on a floodplain, and serviced by poor infrastructures, Pikine soon became the main attraction pole in the Dakar area for people with low-income. Pikine Irregular South (PIS), made up of 5 communes belonging to the Department of Pikine, has developed over four decades thanks to the efforts of its residents. Nowadays, Pikine occupies a strategic position within the Dakar region because it is surrounded by the Senegal's main distribution centres and it is located between the administrative-economic district and the new urban areas planned by the former government of Abdoulaye Wade (2000-2012) (see Fig. 1).

\subsection{Present context of PIS: vulnerability to slum clearance and flooding}

Pikine is in the Dakar region, which occupies only $0^{\prime} 28 \%$ of the country's land, but it concentrates $80 \%$ of its economic activity and $22 \%$ of its population (République du Sénégal-APIX, 2007). A strong real estate pressure in the region forced the National Government in 2000 to request an urban and financial audit report of Dakar (République du Sénégal-APIX, 2006:32). Audit findings concluded that taking into consideration the lack of land for urban uses in Dakar, Pikine's irregular settlements had to be converted to "formal" urban land. Given that $85 \%$ of PIS residents are not "formal" tenants (République du Sénégal-APIX, 2006: 71-77), according to a 1964 Law (République du Sénégal, 1964) the Government can evict them without compensation if a "public interest programme" is approved. Since the settlement is strategically located within the Dakar region, it is no surprise that PIS is particularly prone to attracting "public interest programmes", as is shown in actions promoted by the National Government (case 1) and by development agencies (case 2) (see Fig. 1).

Furthermore, since 1989 PIS faces a recurrent flooding problem. According to the authorities, the problem is mostly due to the irregular occupation of land; however, experts and residents point out the lack of public investment in building a drainage system. Under these circumstances, residents have been fighting for several decades to protect their houses and settlement from flooding (see Fig. 3) and voicing their disagreement with any proposal aimed at removing them from the settlement. 


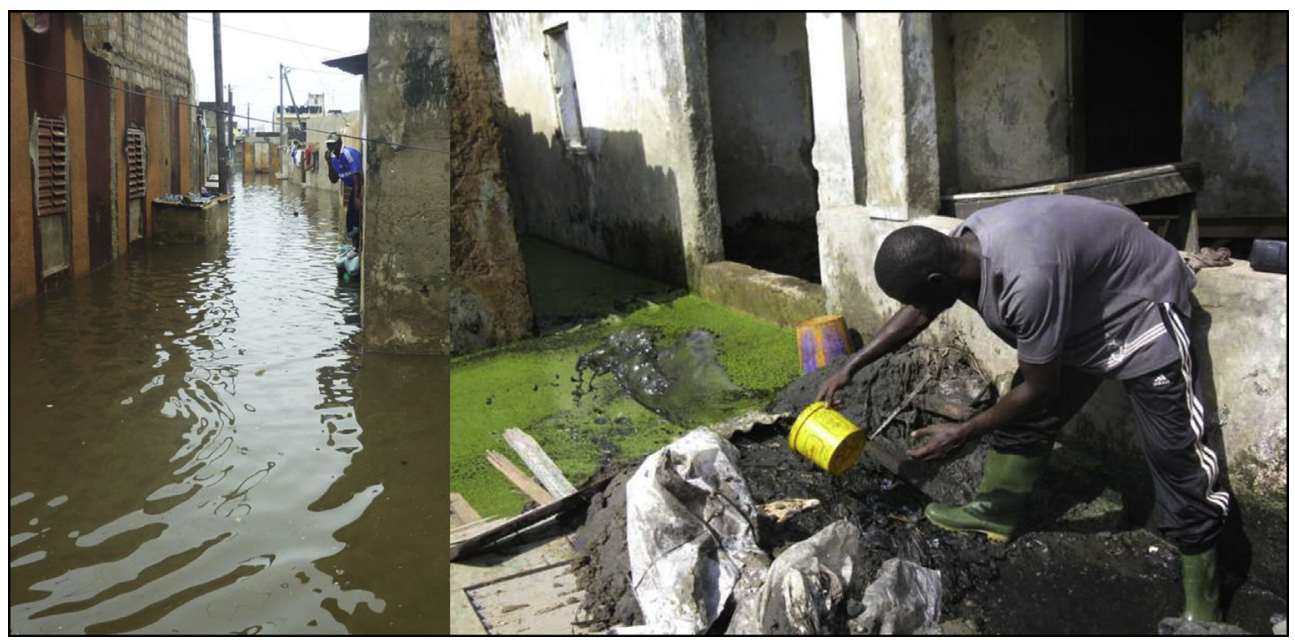

Fig. 3. View of flooding problem. Source: Authors.

\subsection{Brief presentation of the case studies}

In response to the flooding problem in PIS, the National Government decided to start a new programme called "Plan Jaxaay" (case 1). After the flood disaster of 2005, President Abdulaye Wade proposed to get the victims out of the water "as an eagle would do". The National Government, through the Ministry of Housing (MUHCH), promised to build 3000 new dwellings for the affected citizens $22 \mathrm{~km}$ away from the centre of Dakar. The initiative's estimated cost was 79 million euro. This action resulted in the forced relocation of 30,000 persons (République du Sénégal MHUCH, 2009). While the Government considered that this action successfully solved the settlers' problems, the experts considered this programme to be inefficient (World Bank, 2010) and the citizens themselves felt deceived by the Government and considered that they have been impoverished.

On the other hand, in order to attract direct foreign investment the National Government proposed a set of urban mega-projects consisting of building a new airport, a business district and a special economic zone. For these new urban projects to be viable, the World Bank considered that a new toll highway was needed to connect them with the centre of Dakar, and in fact conditioned the financial support to the development of the so called "Highway of the Future" (case 2). The Agency for Investment Promotion and Major Projects (APIX, from its name in French) would be responsible for implementing and monitoring the proposed project. The French corporation Eiffage, with a long-standing presence in Senegal, would build the highway, finance $40 \%$ of the total cost and be entitled for commercial exploitation during the next 30 years. The total cost was estimated at $\mathbf{3 0 5}$ million euro (République du Sénégal-APIX, 2007).

It was argued that the proposed highway would generate new jobs, achieve territorial equilibrium and improve urban mobility. Furthermore, since the project was promoted by the World Bank, this institution would be obliged to comply with its operational policy OP.4.12 about "involuntary relocation". Among other measures, this policy establishes that the Bank must reduce to a minimum the number of involuntary relocations; it must compensate losses borne by affected residents through replacement costs, disregarding their tenure condition; it must relocate the affected persons in an equivalent settlement to the original one; and it must involve citizens in the decision making process (World Bank, 2001). Despite these conditions, the final highway layout produced five times more relocation of residents than other alternative routes. Moreover, the new relocation settlement is $35 \mathrm{~km}$ away from the centre of Dakar; it has a density of 4 inhabitants/ha; and it lacks any significant economic activity.

Besides all this, the World Bank later recognized that the programme might not improve the territorial balance, the manager of APIX stated that the highway was not going to improve urban mobility by itself, and affected citizens declared that they have been impoverished and their social network has been broken.

In this context, the citizens of Guinaw Rails Nord (GRN), which is one of the five communes of Pikine, decided to mobilize themselves as reaction to the lack of effective response by the public authorities to their real needs (case 3). This popular action was supported by All Together for Dignity (ATD) Fourth World, an international movement dedicated to fighting extreme poverty worldwide, and it was aimed at strengthening GRN residents' capabilities to act as a collective group. A local team was created to fight the flooding problem by building and maintaining a drainage system. The action was carried out with simple means accessible to all residents (boots, picks and shovels) so that everyone at GRN could participate in the collective effort (see Fig. 4). Thanks to this initiative, GRN residents are expected to remain in the settlement, which is located only $12 \mathrm{~km}$ away from Dakar centre, it has a compact high density (400 inhabitants/ha) and it has a dense fabric of economic activities. The total cost of this popular initiative during the 2009-2010 period was of $€ 2104$ (Álvarez, 2013).

It is worth noting that the agents in charge of promoting and implementing the three initiatives consider that their actions have contributed to improving the living conditions of residents.

\section{Findings from the application of the analytical framework to the assessment of initiatives promoted by public authorities (cases $1 \& 2$ )}

In this section, the findings from the application of the analytical framework to the cases promoted by public authorities (cases $1 \& 2$ ) are presented and discussed (see Fig. 5). The findings were obtained from the focus groups with people affected by the case study initiatives and then cross-checked with both the stakeholders (through semi-structured interviews) and the existing public documents. 

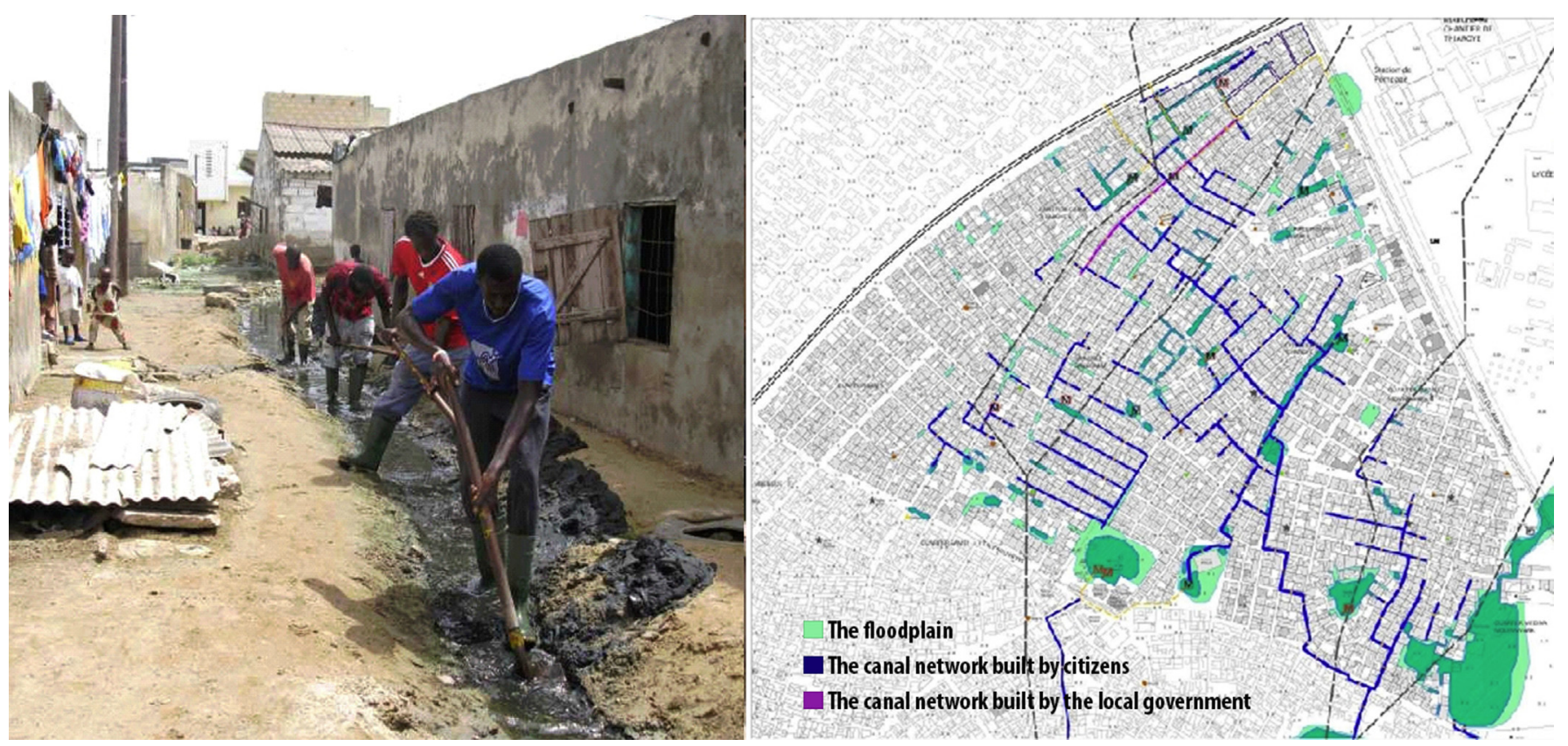

Fig. 4. Drainage system built by citizens.

Source: Authors.

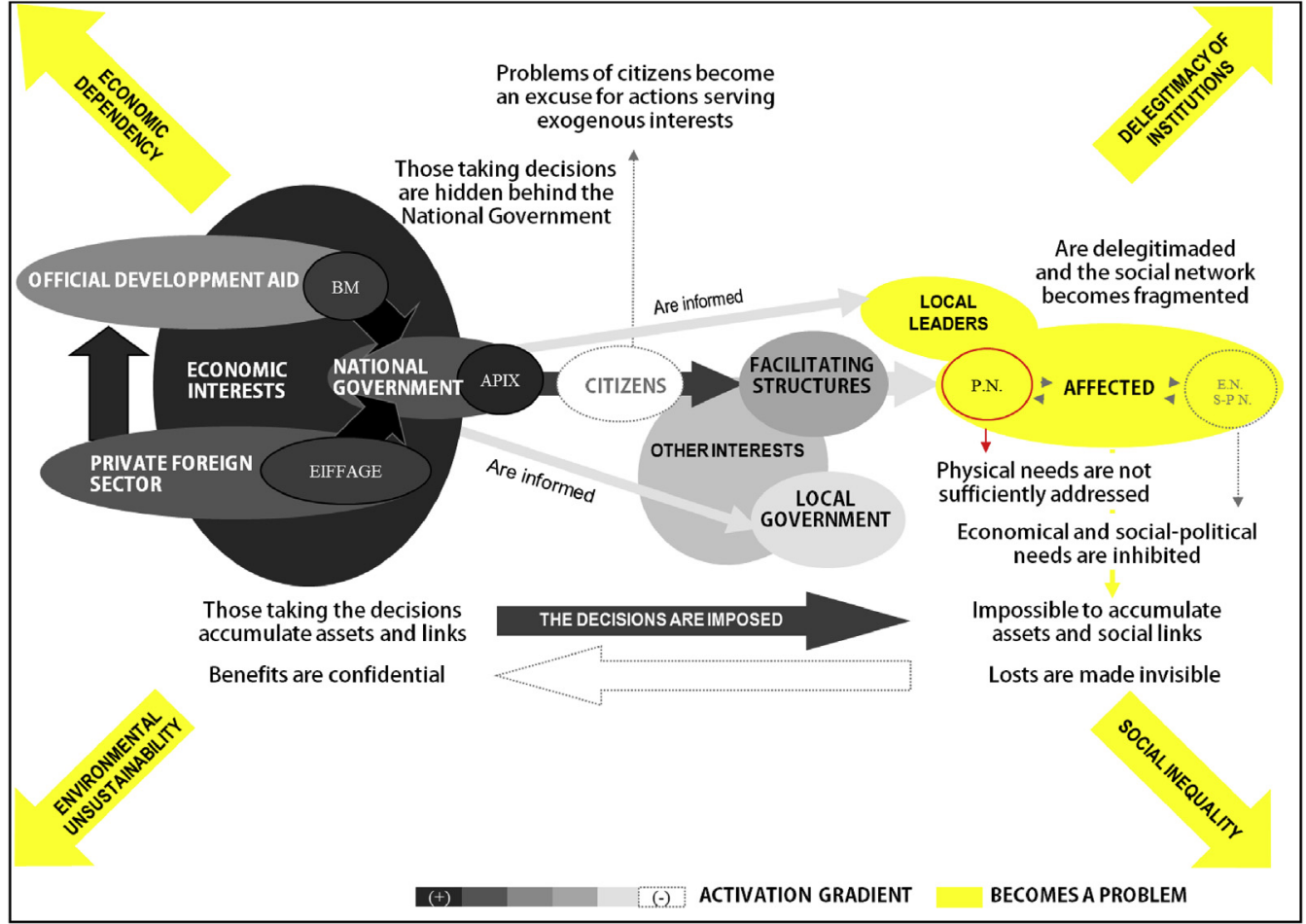

Fig. 5. Display of functional system in cases $1 \& 2$.

Source: Authors.

\subsection{Regarding demand}

In both cases, the satisfaction of the needs of the affected residents was not addressed in an integrated manner by the actors promoting the initiatives. Public agencies held the view that physical improvements "inevitably" involved the relocation of a substantial number of residents to other settlements distant from activity nodes, with lower urban densities and fewer facilities.

With reference to physical needs, the residents affected in case 1 have come from enjoying informal tenure to having no tenure at all; from living in 5-8 room houses to moving to 3 room dwellings where they cannot accommodate large families of 10-15 persons. In case 2, despite conditions established in Operational Policy 4.12, affected residents were compensated for their losses with only $50 \%$ 
of the replacement cost.

With regard to infrastructures, households with lower incomes were excluded from the water and electricity systems because they could not afford the installation costs. In the new settlements, health and educational services were less diverse and access to the transport network was more costly.

As far as economic, societal and political needs, it was observed that these were not taken into consideration either in practice or in the public programme itself. In both cases, the social network of mutual support was fragmented and dispersed, even producing adverse effects in the family structure. The revenue generating activities which were dependent on the central location of the former settlement, the existence of a dense social network and the accessibility to the transport network just did not exist in the new settlement. Besides, the people affected did not participate at all in the decisions related with their relocation process.

Last but not least, the efforts made and the creativity displayed during four decades by the citizens were not only ignored, but also destroyed by the authorities. Participants in focus groups claimed that they had been forced to start from scratch. Indeed, interviewed agents who were responsible for each of these programmes (cases 1 $\& 2$ ) recognized that people affected by these will have to remake their lives by their own means.

Finally, several facts arose: the satisfaction of physical needs was inadequate and insufficient; economic, societal and political needs were neglected; and interrelationships and synergies among the elements of the demand system were inhibited.

\subsection{Regarding supply}

Citizens' problems become a pretext for implementing actions that are ineffective in addressing the problems they supposedly aimed to solve. Though case 1 was a national plan against flooding, $90 \%$ of the action was concentrated on transforming the urban outskirts of Dakar (République du Sénégal - MHUCH, 2009) and it only attended $3 \%$ of the flooding victims. Furthermore, the hydraulic works undertaken were considered useless by some experts. Despite these questionable results, in 2011 "Jaxaay Plan II" was initiated with the support of the World Bank. With regard to case 2 , the programme was intended to generate jobs, achieve territorial equilibrium and improve urban mobility; however, the outcomes are not clear. The World Bank fears that the highway will attract more activity and population to Dakar; the Director of Eiffage-Senac warns that the highway will not solve Dakar's mobility; and some experts, like Chang (2008), argue that this type of programmes generate a greater economic dependence and in the long-run hinder growth and job creation. Despite all these uncertainties, the initiative was launched and it was awarded an additional $83.7 \%$ funds over and above the initial budget estimations.

The people affected by these actions have been impoverished, while the promoters and implementers of initiatives increase their wealth and their network of relationships. In case 1, the State captured the added value of the land expropriated in Pikine as well as the future land appreciation of the new settlements, not for reinvesting it in the community but to gain a profit. In case 2 , the Foreign Private Sector (FPS) will benefit from building an infrastructure. The Eiffage Group, in charge of building the highway, benefited from a $92.67 \%$ increase over the total cost initially estimated. Likewise, the public sector decided to provide $83 \%$ of the total investment, instead of the $64 \%$ initially agreed (République du Sénégal-APIX, 2007). Despite these changes, Eiffage-SENAC will retain the highway concession for 30 years and will get a subsidy of 87 million FCFA for covering part of the toll cost in order to guarantee the project's profitability. On the other hand, the World Bank and the African Development Bank will benefit from debt payments generated by the money loaned to the Senegal Government and Eiffage. Regarding the agencies in charge of preserving the rights of the affected people (APIX, MSA and ENDA Ecopop), they saw their budgets increased 9.6 times above initial estimations. By contrast, the citizens did not come out so well off: compensations to families diminished $40 \%$ with respect to initial agreements; the State took on a debt that was $83 \%$ higher than planned; and once built the highway will benefit only $0.22 \%$ of the Senegalese people (see Fig. 5).

Losses as well as gains have tended to be made invisible. Losses suffered by people are considered to be "inevitable" while gains obtained by promoters, implementers and contractors are considered to be "confidential".

Actions have been imposed through a hierarchical top-down structure. With regard to stakeholders' involvement, in both cases citizen participation was restricted to informative actions. Thus, the local government was entrusted with just gathering information or informing the people.

In case 2, the facilitators (MSA and ENDA Ecopop) were considered by the development agencies as the representatives of the affected people, despite having been hired by APIX, the agency in charge of implementing the plan. In fact, these agencies constrained their role to verifying compliance with Law 64-46, but not with OP.4.12 (Álvarez, 2013). As a focus group participant stated: "you don't bite the hand that nurtures you".

In both cases, it is evident that the National Government took on all responsibility through the programmes' implementers: the Ministry (MHUCH) in case 1 and APIX in case 2.

Finally, it is worth noting that in case 2 its promoters intended to conceal their actions. In one interview given during the research project, a staff member of the World Bank in Senegal recognized that nobody knows them since they work in a location which is unknown to the general public. As a matter of fact, they do not even sign the programmes that they finance, despite recognizing that they have suggested the highway construction, they have promoted the creation of the Presidential Investment Committee (PIC), and they have helped the Government in searching for financial funds and in drawing up operational criteria in the OP.4.12. As a focus group participant said: "It is like the decision-maker staying behind a mirror, so that he can act without being held accountable for his actions". However, as the Dakar Governor said, in the event that there was no compliance with OP.4.12, then the World Bank would be co-responsible with the State for impoverishing the people.

In both cases, the affected people have expressed their suffering caused by the consequences of the transformation programmes, and their impotence in the face of the joint actions of the State, the private sector and the financial sector that have impoverished them.

In conclusion, the supply side has evolved through a top-down hierarchical structure in which the interests of the majority have been displaced by the interests of those who promote and manage resources (ODA, National Government and facilitators) and those who benefit from the process, the Foreign Private Sector (FPS). In the meantime, the affected people are impoverished.

\subsection{Regarding context}

In both cases, the economic dependence increased, the territorial model became more unbalanced, the urban model favoured sprawl and segregation, and the social model preserved inequalities. In this context, the stakeholders involved in the programmes' implementation lost their legitimacy with citizens, while other stakeholders (FPS, ODA) were not visible because they stayed behind the Government. 
In short, neither the integral satisfaction of the affected needs nor their participation in the decision-making process was promoted. Consequently, development actions ended up responding to the interests of those who manage resources and take decisions, instead of attending the community wellbeing. Moreover, this behavioural pattern aggravated the context conditions.

\section{Findings from the application of the analytical framework to the assessment of initiatives promoted by the citizens (case 3)}

In this section, the findings from the application of the analytical framework to the cases promoted by the citizens (case 3 ) are presented and discussed (see Fig. 6). As in the previous section, the findings were obtained from the focus groups with the affected and then cross-checked with both the stakeholders (through semistructured interviews) and the existing public documents.

\subsection{Regarding demand}

The leaders of the initiative took as their starting point that the satisfaction of needs in an urban transformation process has to be approached in an integral manner. In case 3, an improvement of physical conditions was proposed as a means to strengthen the socio-political needs of the community. The action sought to ensure that the GRN citizens affected by the flooding problem could remain in the settlement and, consequently, make effective their efforts to build their houses, manage their settlement and develop economic activities. The GRN advisor on environmental issues has recognized that since the action was initiated, nobody has been forced to leave the settlement because of floods. The revenue generating activities undertaken by GRN citizens keep thriving because the settlement is strategically located and it enjoys a dense and reliable social fabric. An action designed by the involvement of all people affected has contributed to promote the understanding among neighbours and it has strengthened the commune's collective identity.

\subsection{Regarding supply}

The core of the action is based on the satisfaction of the integral system of needs. ATD Fourth World and the local leaders constitute the Flood Fighting Team (FFT). This team recognized the affected people as the main agents of the transformation process and it decided to support their efforts.

Therefore, the direct involvement of the people affected became the key driver of the action. In 2009, the FFT built a drainage canal network, but from 2010 on the GRN citizens took on the responsibility for building the canals, while the FFT maintains the works.

Those who promoted the action chose to involve the affected residents, so progress was achieved in a progressive way based on dialogue among the affected. ATD and the local leaders gained the acknowledgement of GRN citizens and became social mediators in the commune.

The lack of support from the rest of stakeholders impeded an effective satisfaction of the set of needs of the affected. Despite the efforts undertaken by the affected and their supporters, no definite satisfaction of the integral system of needs was achieved because of lack of support from the rest of stakeholders (Local Government, National Government and development agencies). Following the action taken in 2009, the Local Government decided to participate in building the canal network to fight floods. In 2010, it invested 18,293 euro to build a canal which just represented $7 \%$ of the total canal network and which could not be drained by gravity like the rest of the system. According to the commune's Environment Advisor, "this canal brought in more problems than solutions". In parallel to this collective initiative, the National Government went on promoting the physical and social transformation of PIS, as described in cases 1 and 2, by increasing the real estate pressure on the commune and subsequently threatening to relocate GRN citizens from their settlement.

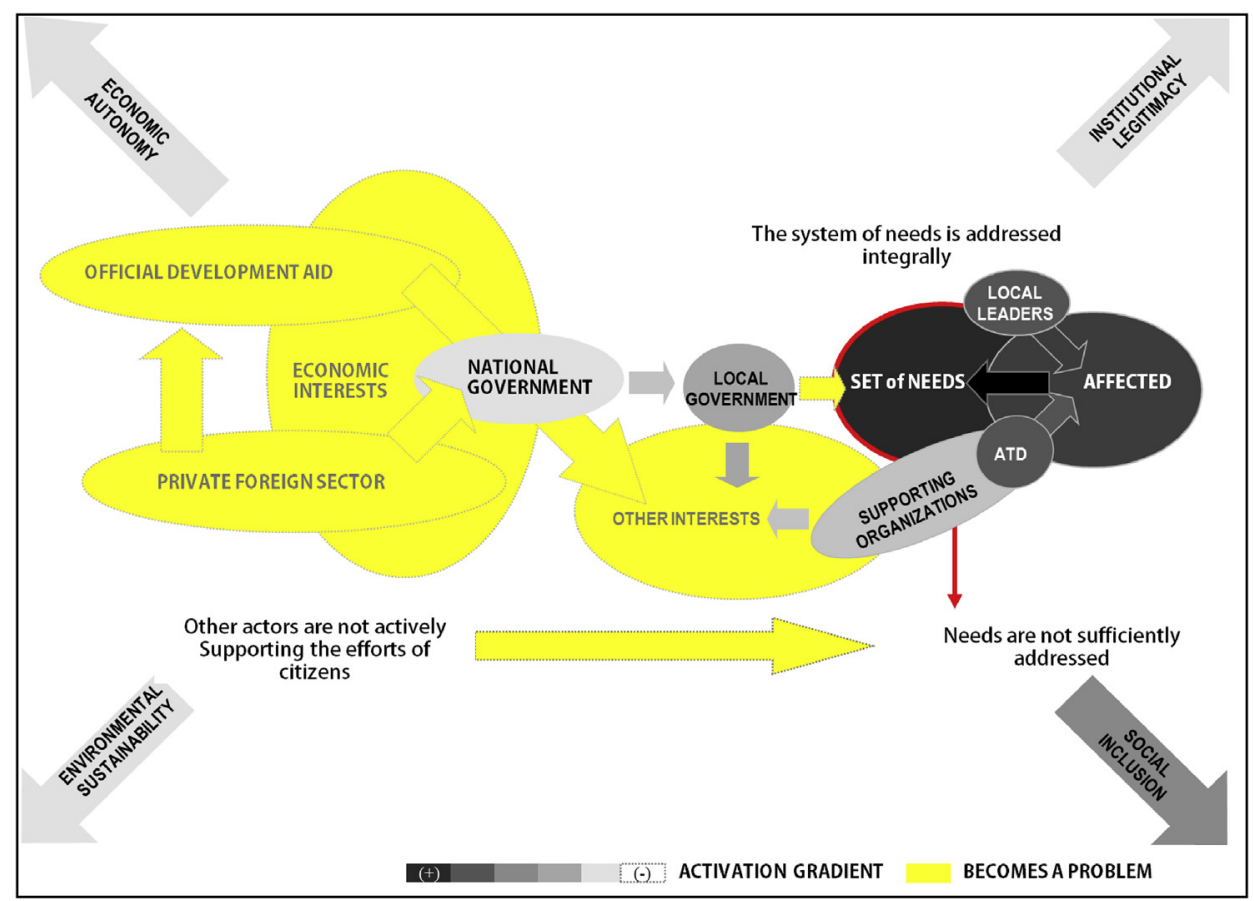

Fig. 6. Display of functional system in cases 3. 
Summing up, the supply side in case 3 has been shaped as a non hierarchical bottom-up structure, in which ATD and local leaders have supported GRN citizens in their efforts to satisfy their integral system of needs. However, the major pitfall of this case was the lack of involvement of other stakeholders (FPS and ODA) and/or the participation of other stakeholders driven by their own interests (National Government, Local Government and other support organizations). Both behaviours explain why it has not been possible to give a proper response to the integral system of needs of the affected people.

\subsection{Regarding context}

Case 3 was characterized by the use of local resources by all residents, the preservation of a compact and integrated urban model and the development of an equitable social model. Moreover, it has been observed that the stakeholders involved in the action gained legitimacy among the GRN citizens affected and the rest of the institutions.

In brief, the integral satisfaction of residents' needs and the involvement of residents in the decision making process have been promoted; however, due to lack of support from the rest of the stakeholders, who either did not participate or simply acted according to other interests, demand was not appropriately satisfied. Nevertheless, this initiative has contributed to promoting residents' autonomy, to preserving a compact and inclusive urban pattern, and to granting legitimacy to the stakeholders who were involved in the action.

\section{Conclusions}

This paper has shown the importance of analyzing whether different types of policies, programmes and actions for transforming the territory contribute effectively to satisfying in an integral way the needs of those affected and to improving the conditions of the urban environment as a whole.

For that purpose, an analytical framework was designed to analyze complex systems and assess the different ways of responding (supply side) to the needs of the people affected (demand side) within a given urban environment (context). The systematic application of this method to three case studies related to the spatial and social transformation process experienced by the largest self-made settlement in the urban periphery of Dakar has drawn the following conclusions:

- Regarding demand, it has been shown that those actions in which exogenous interests have prevailed over the satisfaction of the integral needs of the people affected have ended up impoverishing local residents.

- Regarding supply, it has been seen that those actions in which involvement of people affected in the decision making process has not been effectively promoted, have resulted in benefiting those who manage resources and take decisions.

- Regarding context, it has been established that when no integral satisfaction of the needs of the people affected and no effective involvement in the decision making process take place, then context conditions get worse; in other words, there is an increase in economic dependence, environmental impacts, social inequity and institutional illegitimacy.

The proposed functional system has shown its capacity to analyze the complexity of real operational processes; that is the positioning and relevance of each of the system's elements as the interrelationships among elements. The analytical framework has been particularly useful to assess the level of satisfaction of the needs of people affected by the case study initiatives, their involvement in the decision making process and the impacts on the urban context. Additionally, the tools employed to gather and process information have allowed incorporating into the research a wide range of stakeholder opinions, particularly of those who tend to become invisible.

In brief, the methodological approach used in this paper has proven useful in providing a more integral understanding of the societal and spatial transformation processes which occur in places with high urban growth, but no or negligible economic development. This phenomenon exposes the myth of the supposedly perfect approach espoused by the international agency reports (World Bank, 2000; Un-Habitat 2003, 2009) regarding the supposed neutrality of stakeholders' relations. Some evidences arise from our research:

- Despite the efforts made by the citizens themselves to improve their neighborhoods, they were not recognized by the public authorities. In fact, their actions were ignored or destroyed, forcing them to start all over again in a new settlement which was badly located and with much fewer facilities. Moreover, the extremely low density of the new settlement became an obstacle for the survival of productive activities and weakened social networks. The people evicted from PIS have created the roots for a new "informal" settlement which is likely to suffer from another eviction cycle in the future.

- The National Government, instead of satisfying the needs of the majority of the citizens, acted as "facilitator of capital accumulation", thus losing its legitimacy in front of the citizens. This attitude means that citizens loose power since they do not have any stakeholder eager to defend their interests in the decisionmaking process.

- The development agencies, instead of trying to solve the problems of poverty and social exclusion, have contributed to perpetuating them.

- Key official stakeholders such as funding agencies, national and local authorities, private sector and NGOs bound themselves to a strongly hierarchical structure, articulated in a top-down fashion, which provided support to financial promoters of development actions. Hence, foreign private investors were hidden behind other actors, such as the National Government, thus in effect eschewing any responsibilities for the consequences of the implementation of actions and programs promoted by them.

Though the previous outcomes are derived from specific case studies and, therefore, are context-dependent, similar results may be expected from other cases in similar contexts.

In any case, the key challenge remains in defining what is "common good" in a real political context, where power forces are unequal (Jenkins et al., 2007). Accordingly, it is recommended to refine the proposed method by applying it to other cases and testing its validity. Additionally, it would be convenient to keep researching how to strengthen the capabilities of citizens and communities so that they get involved in the decision making processes and break the inequality of power forces (Escobar 2005; Frediani, 2007). To put it differently, we have to make an effort to eliminate unjust and inappropriate policies which are implemented in favour of a minority and to the detriment of a majority (Harvey, 2012).

\section{References}

Álvarez, E. (2013). Intereses exógenos y resistencia ciudadana en la transformación físico-social de un asentamiento auto-producido de Dakar (2005-2011). PhD Tesis 
2013. Departamento de urbanística y ordenación del territorio, Universidad Politécnica de Madrid.

Anderson, P. (1983). Decision making by objection and the cuban missile crisis. Administrative Science Quarterly, 28, 201-222.

Belil, M., Borja, J., \& Corti, M. (Eds.). (2012). Ciudades una ecuación imposible. Icaria: Barcelona.

Bredenoord, J., \& van Lindert, P. (2010). Pro-poor housing policies: rethinking the potential of assisted self-help housing. Habitat International, 34(3), 278-287.

Burgess, R. (1992). Helping some to help themselves: third world housing policies and development strategies. In K. Mathey (Ed.), Beyond self-help housing. London: Mansell Publishing Limited.

Burgess, R., Carmona, M., \& Kolstee, T. (Eds.). (1997). The Challenge of sustainable cities. Neoliberalism and urban strategies in developing countries. London: Zed Books ltd.

Chang, J.-H. (2008). ¿Que fue del buen samaritano? Naciones ricas, políticas pobres. Barcelona: Intermon Oxfam.

Davis, M. (2006). Planet of slums. London: Verso.

Dorier-Apprill, E. (2000). Dakar et son double. Paris: Editions du temps.

Durand Lasserve, A., \& Ndiaye, S. (2008). The social and economic impact of land titling programmes in Dakar, Senegal; Main findings of the socio-economic survey in five settlements in Dakar and Pikine (Appendix A: Senegal case study report).

ENDA (Ed.). (2008). H. Expériences du Sénégal. La réduction des risques de catatrophes naturelles en Afrique de l'Ouest et en Afrique Central: Perspectives locales. Dakar: Enda Editions.

Escobar, A. (2005). El "postdesarrollo" como concepto y práctica social. In D. Mato (Ed.), Políticas de economía, ambiente y sociedad en tiempos de globalización (pp. 17-31). Caracas: Facultad de Ciencias Económicas y Sociales, Universidad Central de Venezuela.

Fall, A. (2007). Bricoler pour survivre. Perceptions de la pauvreté dans l'agglomération urbaine de Dakar. Paris: Khartala.

Fernández-Güell, J. M. (2006). Planificación estratégica de ciudades: Nuevos instrumentos y procesos. Barcelona: Editorial Reverté.

Frediani, A. A. (2007). Housing Freedom, Amartya Sen and Urban Development Policies - Squatter Settlement Upgrading in Salvador da Bahia, Brazil. Ph.D Thesis. Oxford Brookes University.

Freire, P. (1970). Cultural action for freedom. Harvard: Harvard Educational Review.

Gaye, M. (1992). The self-help production of housing and the living environment in Dakar, Senegal. Environment and Urbanization, 4(2), 101-108.

Gersick, C. (1988). Time and transition in work teams: toward a new model of group development. Academy of Man- agreement Journal, 31, 9-41.

Harris, S., \& Sutton, R. (1986). Functions of parting ceremonies in dying organizations. Academy of Management Journal, 29, 5-30.

Harvey, D. (2012). Rebel cities: From the right to the city to the urban revolution. London: Verso.

Jenkins, P., Abiko, A., Frediani, A. A., \& Moraes, O. (2010). Urban upgrading interventions and engaging residents in fuzzy management: case studies from Novos Alagados, Salvador, Brazil. Habitat International, 34(1), 105-114.

Jenkins, P., Smith, H., \& Wang, Y. P. (2007). Planning and housing in the rapidly urbanising world. New York: Routledge.

Kauffman, S. (1995). At home in the Universe: The search for the laws of selforganization and complexity. Nueva York: Oxford University Press.

Kidder, T. (1982). Soul of a new machine. New York: Avon.

Landman, K., \& Napier, M. (2010). Waiting for a house or building your own? Reconsidering state provision, aided and unaided self-help in South Africa. Hábitat International, 34(3), 299-305.

Marais, L., \& Ntema, J. (2013). The upgrading of an informal settlement in South Africa: two decades onwards. Habitat International, 39, 85-95.

Max-Neef, M., Elizalde, A., \& Hopenhayn, M. (2010). Desarrollo a escala humana: Una opción para el futuro. Retrieved from. Madrid: Biblioteca $\mathrm{CF}+\mathrm{S}$ http://habitat.aq. upm.es/deh/adeh.pdf.

Michelutti, E., \& Smith, H. (2014). The realpolitik of informal city governance. The interplay of powers in Mumbai's un-recognized settlements. Habitat International, 44, 367-374.

Mitlin, D. (2008). Urban poor funds; development by the people for the people. In Poverty reduction in urban areas series. London: IIED. Working Paper 18.

Moser, C. (1998). The asset vulnerability framework: reassessing urban poverty reduction strategie. World Development, 26(1), 1-19.

Myrdal, G. (1972). The Challenge of world poverty.

Neuwirt, R. (2011). El bazar global. Ciudades: Investigación y ciencia.

Payne, G. (2002). Land, rights and innovation: Improving tenure security for the urban poor. London: ITDG.

Payne, G., Durand-Lasserve, A., \& Rakodi, C. (2009). The limits of land titling and home ownership. Environment and Urbanization, 21(2), 443-462.

Peris, J., Acebillo-Baqué, M., \& Calabuig, C. (2011). Scrutinizing the link between participatory governance and urban environment management. The experience in arequipa during 2003-2006. Habitat International, 35, 84-92.

Pinfleld, L. (1986). A field evaluation of perspectives on organizational decision making. Administrarive science quarterly, 31, 365-388.

Post, J., \& Mwangi, S. (2009). Constraints on neighbourhood activism: experiences with services upgrading in Nakuru, Kenya. Urban Studies, 46(3), 665-686.

Purcell, M. (2002). Excavating lefebvre: the right to the city and its urban politics of the inhabitant. GeoJournal, 58(2-3), 99-107.

République du Sénégal. (1964). Loi 64-46 du 17 Juin 1964, Relative au Domaine National.

République du Sénégal. (2006). Plan Directeur d'Urbanisme de Dakar horizon "2025" Republique du Sénégal-Agence Nationale chargée de la Promotion de l' Investissement et des Grands Travaux (APIX).

République du Sénégal. (2006). Evaluation Environnementale et Sociale du projet d'autoroute dakar - Diamniadio. In Evaluation Environnementale et Sociale de l'emprise du trace de l'autoroute Dakar-Diamniadio (Vol. 1) (Rapport final, Buursink).

République du Sénégal. (2006). Evaluation Environnementale et Sociale du projet d'autoroute dakar - Diamniadio. In Evaluation Environnementale et Sociale du site de recasement de keur (Volume 2) (Rapport final, Buursink).

République du Sénégal. (2007a). Le projet de l'Autoroute a péage Dakar-Diamniadio.

République du Sénégal. (2007b). Cadre Politique de Reinstallation: L'autoroute a peage Dakar - Diamniadio.

République du Sénégal - Minitarire de l'Habitat, l'Urbanisme, la Construction et l'Hydorlique MHUCH. (2009). Projet de construction de logements sociaux, de lutte contre les inondations et les bidonvilles (Plan Jaxaay). Retrieved from http:// www.habitat.gouv.sn/?Projet-de-construction-de.

Ridge, T., \& Wright, S. (2008). Understanding inequality, poverty and wealth: Policies and prospects. Bristol: The Policy Press.

Salem, G. (1998). la santé dans la ville. Géographie d'un petit espace dense: Pikine (Sénégal) (p. 360). Karthala-IRD-ORSTOM.

Satterthwaite, D. (2008). Editorial: the social and political basis for citizen action on urban poverty reduction. Environment and Urbanization, 20(2), 307-318.

Scott, P., Cotton, A., \& Sohail Khan, M. (2013). Tenure security and household investment decisions for urban sanitation: the case of Dakar, Senegal. Habitat International, 40, 58-64.

Shiva, V. (2005). Hacer que la pobreza sea historia, y la Historia de la Pobreza. Cómo poner fin a la pobreza. Rebelión. Retrieved from http://www.rebelion.org/ noticia.php?id=15959.

Taleai, M., Sliuzas, R. V., \& Flacke, J. (2014). An integrated framework to evaluate the equity of urban public facilities using spatial multi - criteria analysis. Cities, 40(A), 56-69.

Tunas, D., \& Peresthu, A. (2010). The self-help housing in Indonesia: the only option for the poor? Habitat International, 34(3), 315-322.

UN-Habitat. (2003). The challenge of slums: Global report on human settlements 2003. London: Earthscan.

UN-Habitat. (2009). Planning sustainable cities: Global report on human settlements 2009. London: Earthscan.

Vernière, M. (1977). Dakar et son double. Dagoudane-Pikine. Volontarisme d'Etat et spontanéisme populaire. Paris: Imprimerie nationale.

Von Bertalanffy, L. (1968). General systems Theory: Foundations, development and applications. New York: Braziller.

Waldrop, M. (1992). Complexity: The Emerging science at the edge of order and chaos. New York: Simon \& Schuster.

World Bank. (2000). World Development Report 2000/2001. Washington DC. The World Bank.

World Bank. (2001). The world bank operational manual: Operational policies OP 4.12 Retrieved from http://siteresources.worldbank.org/INTFORESTS/Resources OP412.pdf.

World Bank. (2010). Project information document (PID: P122841): Flood prevention and drainage project. Retrieved from http://reliefweb.int/sites/reliefweb.int files/resources/0826277B00398291852577F10076904B-Full_Report.pdf.

Wresinnski, J. (1980). El pensamiento de los más pobres. Movimiento Cuarto Mundo. Retrieved from http://www.movimiento-cuartomundo.org/EL-PENSAMIENTODE-LOS-MAS-POBRES.html. 